\title{
Strategic planning for city networks: The emergence of a Basque Global City?
}

Evert Meijers, OTB Research Institute for Housing, Urban and Mobility Studies, Delft University of Technology

e.j.meijers@tudelft.nl

Joris Hoekstra, OTB Research Institute for Housing, Urban and Mobility Studies,

Delft University of Technology

j.s.c.m.hoekstra@tudelft.nl

Ricardo Aguado, Orkestra-Basque Institute of Competitiveness

raguado@orkestra.deusto.es

Keywords:

Polycentric urban regions, EusKal Hiria, Basque Global City, competitiveness

JEL Codes:

$\mathrm{R} 11, \mathrm{O} 18, \mathrm{O} 33$ 


\section{A Strategic planning for city networks: The emergence of a Basque Global City?}

Throughout Europe, policy-makers are developing policies to foster the spatial, economic and social development of what is, in the literature, often termed 'polycentric urban regions': a regional cluster of close-by cities. It is assumed that taking a set of relatively small or medium-sized cities together opens up possibilities for regional economic growth. In this paper we put forward that the simple fact that a region is polycentric does not necessarily mean that it is more competitive. For that to happen, it needs to evolve into a well integrated urban network characterised by an optimal use of its critical mass, exploitation of complementarities and by spatial interaction.

Strategic planning for the development of such polycentric urban regions in many cases involves planning on a relatively new scale, based upon new starting points and taking on board new strategic objectives. This paper presents one of the first (1990s) territorial development visions for polycentric urban regions, the territorial development strategy for the Basque autonomous region. The key idea of this strategy, labeled Euskal Hiria ('Basque Global City'), is exactly aimed at developing the networking between its three main cities (Bilbao, San Sebastian and Vitoria).

\section{Planificación estratégica para nodos de ciudades: ¿la aparición de una ciudad vasca global?}

A lo largo y ancho de Europa, la clase política está desarrollando políticas para favorecer el desarrollo espacial, económico y social de lo que en la literatura se denomina "regiones policéntricas urbanas": un cluster regional formado por ciudades cercanas. La literatura asume que al agrupar una serie de ciudades de tamaño pequeño o mediano se favorecerán las posibilidades de lograr un mayor desarrollo regional. En este trabajo desarrollaremos la idea de que el mero hecho de que una región sea policéntrica no implica necesariamente que vaya a ser más competitiva. Para que eso suceda debe darse una evolución desde el simple policentrismo hacia la configuración de un nodo urbano bien integrado, caracterizado por un uso óptimo de su masa crítica, de las complementariedades entre núcleos urbanos y de la interacción espacial.

La planificación estratégica para el desarrollo de regiones policéntricas urbanas requiere, en muchos casos, una planificación a partir de nuevas escalas, basadas en nuevos puntos de partida y teniendo en cuenta nuevos objetivos estratégicos. Este trabajo presenta una de las primeras (1990) visiones para el desarrollo de regiones urbanas policéntricas, la estrategia de desarrollo territorial para la Comunidad Autónoma del País Vasco. La idea principal de esta estrategia, denominada Euskal Hiria (ciudad vasca) consiste en desarrollar las interacciones entre las tres capitales vascas (Bilbao, Vitoria y San Sebastián.

\section{Hiri nodoetarako plangintza estrategikoa: euskal hiri globala azaltzen ari al da?}

Europa osoan zehar, politikariak politikak garatzen ari dira literaturan "hiri eskualde polizentriko" deitutakoen garapen espaziala, ekonomikoa eta soziala bultzatzeko. Hiri eskualde polizentrikoak elkarrengandik hurbil dauden hiriek osatutako eskualdeko klusterrak dira. Literaturak aditzera ematen digu hainbat hiri txiki edo ertain multzokatzen baditugu, eskualdeko garapen handiagoa lortzeko aukera gehiago izango direla. Lan honetan azaldu nahi dugu ez dela zuzena ondorioztatzea eskualde bat polizentrikoa bada, zuzenean lehiakorragoa izango dela. Izan ere, lehiakorra izateko, polizentriko huts izatetik ongi integratutako hiri nodo izatera pasatu behar da. Hiri nodo horren ezaugarri izango dira masa kritikoaren, hiriguneen arteko osagarritasunaren eta espazioko elkarrekintzaren erabilera onena.

Hiri eskualde polizentrikoak garatzeko plangintza estrategikoak eskatzen du, kasu askotan, plangintza egiteko eskala berrietatik abiatzea, abiapuntu berrietan oinarritzen direnak, eta helburu estrategiko berriak kontuan hartzen dituztenak. Lan honetan hiri eskualde polizentrikoak garatzeko lehenengo ikuspegietako bat (1990) aurkezten dugu, Euskal Autonomia Erkidegoko lurralde garapeneko estrategia. Estrategia horrek Euskal Hiria izena hartu du eta ideia nagusia da EAEko hiru hiriburuen arteko (Bilbo, Gasteiz eta Donostia) elkarrekintzak garatzea. 


\section{INTRODUCTION: STRATEGIC PLANNING FOR CLUSTERS OF CITIES}

While during the 1980 s urban and regional planning mainly focused on specific development projects and land use regulation, we have witnessed a re-emergence of comprehensive, strategic spatial planning for cities, city-regions and regions from the 1990s onwards (Salet and Faludi, 2000; Albrechts et al., 2003). Strategic spatial planning aims to provide an integrated framework for territorial development and investments projects.

From a substantive point of view, a major theme in many strategic territorial development plans has become 'polycentric development'. This appears largely due to its insertion in the 1999 European Spatial Development Perspective (CEC, 1999; Faludi and Waterhout, 2002; Davoudi, 2003). One reason for the popularity of this concept is its promise of linking potentially conflicting objectives such as competitiveness, cohesion and sustainability. The objective of polycentric development is currently being taken further in the current debate about a European territorial cohesion policy (Faludi, 2005, 2006; Council of the European Union, 2006; CEMAT, 2006; EU Ministers Responsible for Spatial Planning and Development, 2007; Tatzberger, 2008).

At present, explicit planning for such polycentric urban regions is a feature of strategic regional development strategies in many European countries (see Meijers, 2005), although such regional clusters of cities are generally not referred to as polycentric urban regions. Rather, policy makers often refer to them as 'urban networks' or 'city networks'. Use is made of the network metaphor to emphasise the alleged or desired complex and strong relationships between the cities and as such the coherence and unity of the region.

Planning for polycentric urban regions in many cases involves planning on a relatively new scale, based upon new starting points and taking on board new strategic objectives (Lambregts, 2000). Exemplary in this case is one of the first (1990s) elaborated territorial development visions for polycentric urban regions, the territorial development strategy for the Basque autonomous region in Spain. The key idea of this strategy, labeled Euskal Hiria ('Basque Global City'), is that the critical mass of the Basque autonomous region can be increased if its three capital-cities (Bilbao, San Sebastian and Vitoria) are complementary to each other, and if they are 
integrated in a polycentric urban network with many interactions and co-operation between each of the cities, as well as with the rest of the territory.

In this contribution, we explore the leverage of the strategic regional development strategy for the Basque autonomous region, aimed at 'knitting' together its three main cities into one 'Basque Global City'. In what sense has it been able to provide a policy framework capable of directing and anticipating future spatial developments, and to actually mobilise spatial actors to take the necessary steps to shift the Basque Country's territorial development trajectory in such a way that an urban network - in the true sense of the word - has emerged?

In answering this research question, we build on the recent academic debate on the spatial organisation and functioning of polycentric urban regions and the challenges of strategic spatial planning in such regions. We adopt a two-step approach. First, we will assess to what extent the vision on the desired spatial development of the polycentric urban system in the Basque autonomous region has 'materialized' in practice. This analysis addresses a 'functional' dimension. Second, we turn to a more general discussion on the impact of spatial development strategies and consider whether some basic requirements for effective spatial development are met in the Basque autonomous region.

The paper is structured as follows. In section 2, we start with a brief theoretical review of what should be considered the main spatial development challenge in polycentric urban regions. This challenge can be characterised as developing the collection of cities into a well integrated urban network. In section 3 we present the territorial development strategy of the Basque autonomous region and examine how it deals with this challenge, next to providing a brief introduction of this region. In section 4 we will empirically analyse the extent to which the three cities in the Basque autonomous region have evolved on their path to becoming a well integrated urban network. More specifically, three issues will be explored in detail: critical mass, complementarities and spatial interactions. In section 5 , we provide a more general discussion of the effectiveness of spatial development strategies and consider whether some basic requirements for effective strategic spatial planning are met in the Basque autonomous region. We round of with a concluding section 6. 


\section{THE DEVELOPMENT CHALLENGE: FROM POLYCENTRIC URBAN REGION TO URBAN NETWORK}

The fact that in so many European countries policy makers have identified a cluster of close-by cities as a relevant spatial entity to plan for, demonstrates the great potential that is commonly attributed to such regions. However, the simple fact that a region is polycentric does not necessarily mean that it is more competitive. For that to happen, it needs to evolve into a well integrated urban network (Meijers, 2007a). While a polycentric urban region can be basically identified on the basis of the 'image on the map' (a clustering of cities), an urban network is characterised by features such as size neutrality, complementarity, nodality, horizontal accessibility, and twoway flows between cities, which reflect the regionalisation of once local housing and labour markets (Batten, 1995; Van der Knaap, 2002; Meijers, 2007a). If a polycentric urban region wants to be competitive, it needs to evolve into an urban network.

In order to assess whether and to what extent a polycentric urban region has developed into an urban network, several aspects need to be considered. This includes an analysis of the critical mass present in the region and to what extent it actually is exploited, an analysis of complementarities between the cities as well as an analysis of interactions between the cities (or the actors within them). However, we start with an introduction to our case study region and present the strategic spatial development strategy of the Basque autonomous region in more detail.

\section{THE BASQUE STRATEGIC TERRITORIAL DEVELOPMENT STRATEGY}

The development challenge described above has been recognised in the Basque autonomous region as well. Before exploring the spatial development strategy in more detail, we will first introduce the Basque autonomous region and its major cities.

\subsection{The Basque Country}

The Basque autonomous region with over 2 million inhabitants is located in the north of Spain. It consists of three provinces: Alava, Bizkaia, and Gipuzkoa. The Basque Country is characterized by a polycentric urban system. The three capitals of the 
provinces are the main cities and are located within reasonable distance of each other. These cities are Bilbao, San Sebastian and Vitoria. They are the centre of a bigger area that is closely related to the central city. In this paper we use these bigger areas (so-called comarcas) as the unit of analysis. Table 1 provides basic statistics on these city-regions.

Table 1 Basic indicators of the three Basque city-regions

\begin{tabular}{|c|c|c|c|}
\hline & $\begin{array}{l}\text { Gran } \\
\text { Bilbao } \\
\text { (Bilbao) }\end{array}$ & $\begin{array}{l}\text { Llanada } \\
\text { Alavesa } \\
\text { (Vitoria) }\end{array}$ & $\begin{array}{l}\text { Donostialdea } \\
\text { (San } \\
\text { Sebastian) }\end{array}$ \\
\hline Population city-region(2005) & 871.661 & 239.943 & 318.685 \\
\hline Population core city (2006) & 351.179 & 229.668 & 180657 \\
\hline Surface in square kilometres (2005) & 372 & 785 & 306 \\
\hline $\begin{array}{l}\text { Population density (habitants } / \mathrm{km}^{2} \text { ) } \\
\text { (2004) }\end{array}$ & 2360 & 306 & 1044 \\
\hline Foreign-born population (\%) (2006) & 3,9 & 6,1 & 5,1 \\
\hline GDP per capita $€(2001)$ & 17.512 & 22.267 & 18.665 \\
\hline Unemployment in \% (2001) & 14,5 & 10,0 & 11,0 \\
\hline $\begin{array}{l}\% \text { of the active population working in } \\
\text { the municipality where they live (2001) }\end{array}$ & 40 & 85 & 51 \\
\hline \% employed in agriculture (2001) & 0,5 & 1,3 & 1,3 \\
\hline \% employed in industry (2001) & 20,3 & 30,7 & 21,0 \\
\hline \% employed in construction (2001) & 9,8 & 7,6 & 8,6 \\
\hline \% employed in services (2001) & 69,4 & 60,4 & 69,1 \\
\hline Average house price $\left(€ / \mathrm{m}^{2}\right)(2007)$ & 4271 & 3059 & 3810 \\
\hline
\end{tabular}

Source: Instituto Vasco de Competividad, 2007, Spanish ministry of Housing (www.mviv.es)

Institutional and political context

The political context of the Basque country is rather complicated since there are no less than five different tiers of government involved: the European Union, the Spanish central government, the regional government, the provinces and the municipalities.

The Basque autonomous region has its headquarters in Vitoria and is responsible for, among other things, education, health care and spatial planning. In section 3.2 the spatial planning policies of the Basque autonomous region are discussed in more detail. 
For historical reasons, the three provinces (Alava, Vizcaya, and Gipuzkoa) are of particular importance in this part of the Basque country. They coincide with the socalled historical territories, entities that have always enjoyed substantial autonomy in the past. The provinces have competences in areas such as urban development and infrastructure. In contrast with other provinces in Spain (except Navarra), they have considerable financial power since they are responsible for the collection of the general income and corporation taxes. Each of the three provinces defines its own tax regime. The provinces subsequently transfer part of the tax resources to the Spanish government, the Basque government and the municipalities. This strong position in terms of competences and resources of the provinces implies that the regional Basque government is rather dependent on their co-operation.

There are 250 municipalities in the Basque autonomous region, many of them very small. The municipalities raise local taxes and are responsible for building projects and public services at the municipal level.

\subsection{Strategic spatial development strategy: towards a 'Basque Global City'}

The Basque government is responsible for spatial planning within the autonomous region. In the early 1990s, it developed an approach that focused on the strengthening of a polycentric urban system in the region. The main idea was to structure the regional development of the Basque autonomous region around the further development of the polycentric urban network Bilbao - Vitoria - San Sebastian. The above vision was presented in a policy document that was published in 1997: Directrices de Ordenación Territorial de la CAPV (DOT Euskadi).

The ideas on polycentric development that were proposed in DOT Euskadi were further developed in the publication Euskal Hiria. The Euskal Hiria vision starts from the observation that in the global competition between cities critical mass is important, and that consequently only cities of a certain size have the potential to attract the specialized services that are so important for innovation and competitiveness. The key idea of Euskal Hiria is that the critical mass of the Basque region can be enhanced if the three main urban areas in the region are complementary to each other, and if they are integrated in an urban network characterised by many interactions between each of the cities, as well as with the 
rest of the territory. The Euskal Hiria strategic development vision presents several propositions to strengthen its network of major cities:

- More cooperation between the three Basque cities with regard to spatial and economic planning. The focus should be on cooperation instead of competition;

- An improvement of the infrastructure that connects the three Basque cities. In this respect, especially the future high-speed train connections linking Bilbao and San Sebastian with Vitoria are considered to be important;

- Better connections and more cooperation with the cities and regions outside Basque country;

\section{SYNERGY BETWEEN THE BASQUE CITIES}

Van Houtum and Lagendijk (2001) present a pessimistic view on the extent to which synergies between the Basque cities have developed, stating that the idea of a Basque urban network is based on geostrategic considerations (Basque country as the crossroad of important economic corridors) and a strong cultural identity rather than on functional integration in practice. Here, we present an empirical assessment of Van Houtum and Lagendijk's conviction. As synergy derives from an optimisation of critical mass, from complementarities and from interactions, we explore these three issues in the subsequent subsections.

\subsection{Critical Mass}

Taken together the three city regions in the Basque Country have approximately 1.5 million inhabitants. In this section we will explore the extent to which the critical mass of the urban population in the Basque Country is utilized to support several urban functions. The functions included in our analysis are traditionally concentrated in cities and include transport, decision-making, public administration, knowledge, tourism and industry.

We approach the question of how much critical mass is present in the polycentric Basque urban system by comparing the region with city-regions that are of similar size, but, in contrast, have a monocentric spatial structure. In other words, we 
assume that the polycentric Basque urban system is actually one single city-region with a total urban population of close to 1.5 million.

The cities against which the Basque urban system is benchmarked were chosen because they share some common features. Next to a similar critical mass of 1.5 million inhabitants in the functional urban area, this includes their location in the southwest of Europe and the fact that they are not capital cities, and even are quite a distance away from their nation's capital. The benchmark cities chosen are: Valencia, Sevilla, Porto, Turin and Marseille.

For this analysis, we rely on the database on the scale of functional urban areas elaborated within the European Spatial Planning Observatory Network (ESPON) 1.1.1 project (Nordregio et al., 2004). In this research project, city-regions are delimited on the basis of functional criteria, such as for instance travel-to-work areas. The definition of such areas varies slightly across European countries. For the Basque country, three functional urban areas (FUAs) have been defined, centered around Bilbao, San Sebastian and Vitoria. In practice, this is the Greater Bilbao region (947.000 inhab.), just the municipality for Vitoria (226.000 inhab.), and the area incorporated in the San Sebastian FUA includes the settlements along the coast towards France, and even into France. In ESPON terms, it is considered a transborder FUA (393.000 inhab.). Note that the Basque urban system is thus not considered as one FUA, but as three separate FUAs in ESPON 1.1.1.

This ESPON project includes an analysis of the position in the European urban system of each of the 1596 FUAs that were identified in ESPON 1.1.1 on the basis of their major urban functions. Here, we will examine the scores of our five benchmark cities and the three Basque capital cities on these functions. In Table 2, the scores of each of the cities in our benchmark are listed. Next to a separate listing of the three Basque capital cities, we also list the scores of the three cities when taken together: 'Euskal Hiria present' indicates the best score found in one of the three cities at present, and provides insight in the current position of the whole region. This should be understood as the position of the region in case the three capital cities are a rather loosely connected collection of cities. 'Euskal Hiria potential' indicates the scores that would most probably be found when the three cities really were functionally networked - in that case, the urban functions of each city can be summed up. 
Table 2 Ranking on urban functions

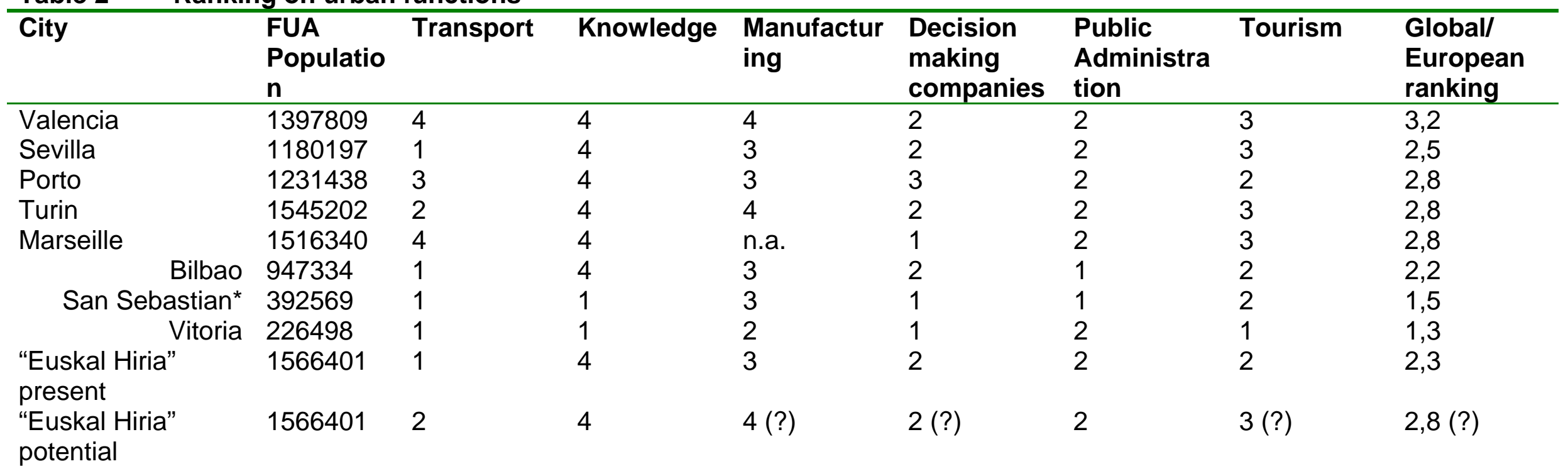




\begin{tabular}{|c|c|c|c|c|c|c|c|c|}
\hline \multirow[t]{3}{*}{ Key to scores } & 5 & $\begin{array}{l}\text { Global } \\
\text { Transport } \\
\text { Hub (more } \\
\text { than 5\% of } \\
\text { European } \\
\text { total) }\end{array}$ & -- & $\begin{array}{l}\text { Global } \\
\text { industrial } \\
\text { node (>20 } \\
\text { billion Euro } \\
\text { in GVA) }\end{array}$ & $\begin{array}{l}\text { Global } \\
\text { decision- } \\
\text { making } \\
\text { centre } \\
\text { (>5\% of top } \\
1500 \\
\text { companies } \\
\text { in Europe) }\end{array}$ & EU Capital & $\begin{array}{l}\text { Global } \\
\text { tourist } \\
\text { attraction } \\
\text { (> 100k } \\
\text { beds) }\end{array}$ & World city \\
\hline & 4 & $\begin{array}{l}\text { Transport } \\
\text { hub of } \\
\text { European } \\
\text { significance } \\
\text { (1-5\% of } \\
\text { European } \\
\text { total) }\end{array}$ & $\begin{array}{l}\text { Knowledge } \\
\text { node of } \\
\text { European } \\
\text { significance } \\
\text { (50-500k } \\
\text { students) }\end{array}$ & $\begin{array}{l}\text { Industrial } \\
\text { node of } \\
\text { European } \\
\text { significance } \\
\text { (7.5-20 } \\
\text { billion euro } \\
\text { in GVA) }\end{array}$ & $\begin{array}{l}\text { European } \\
\text { decision- } \\
\text { making } \\
\text { centre (2- } \\
5 \% \text { of top } \\
1500 \\
\text { companies } \\
\text { in Europe) }\end{array}$ & $\begin{array}{l}\text { National } \\
\text { capital }\end{array}$ & $\begin{array}{l}\text { Tourist } \\
\text { attraction of } \\
\text { European } \\
\text { significance } \\
\text { or strongly } \\
\text { tourist } \\
\text { oriented } \\
\text { (50-100k } \\
\text { beds or > } \\
100 \text { beds } \\
\text { per } 1000 \\
\text { inh.) }\end{array}$ & $\begin{array}{l}\text { City of } \\
\text { global } \\
\text { significance }\end{array}$ \\
\hline & 3 & $\begin{array}{l}\text { Major } \\
\text { Transport } \\
\text { node (more } \\
\text { than 5\% of } \\
\text { national } \\
\text { total but } \\
\text { less than } \\
1 \% \text { of } \\
\text { European } \\
\text { total) }\end{array}$ & $\begin{array}{l}\text { Large } \\
\text { higher } \\
\text { education } \\
\text { institute } \\
\text { (10-50k } \\
\text { students) }\end{array}$ & $\begin{array}{l}\text { Transnation } \\
\text { al industrial } \\
\text { significance } \\
\text { or strongly } \\
\text { industrially } \\
\text { oriented } \\
\text { FUA (2.5- } \\
7.5 \text { billion } \\
\text { Euro in } \\
\text { GVA) }\end{array}$ & $\begin{array}{l}\text { National } \\
\text { decision- } \\
\text { making } \\
\text { centre } \\
(>10 \% \text { of } \\
\text { top } 500 \\
\text { companies } \\
\text { in country; } \\
<2 \% \text { of } \\
\text { European } \\
\text { total) }\end{array}$ & -- & $\begin{array}{l}\text { Major } \\
\text { tourist } \\
\text { attraction } \\
(15-50 k \\
\text { beds) }\end{array}$ & $\begin{array}{l}\text { City of } \\
\text { European } \\
\text { significance }\end{array}$ \\
\hline
\end{tabular}




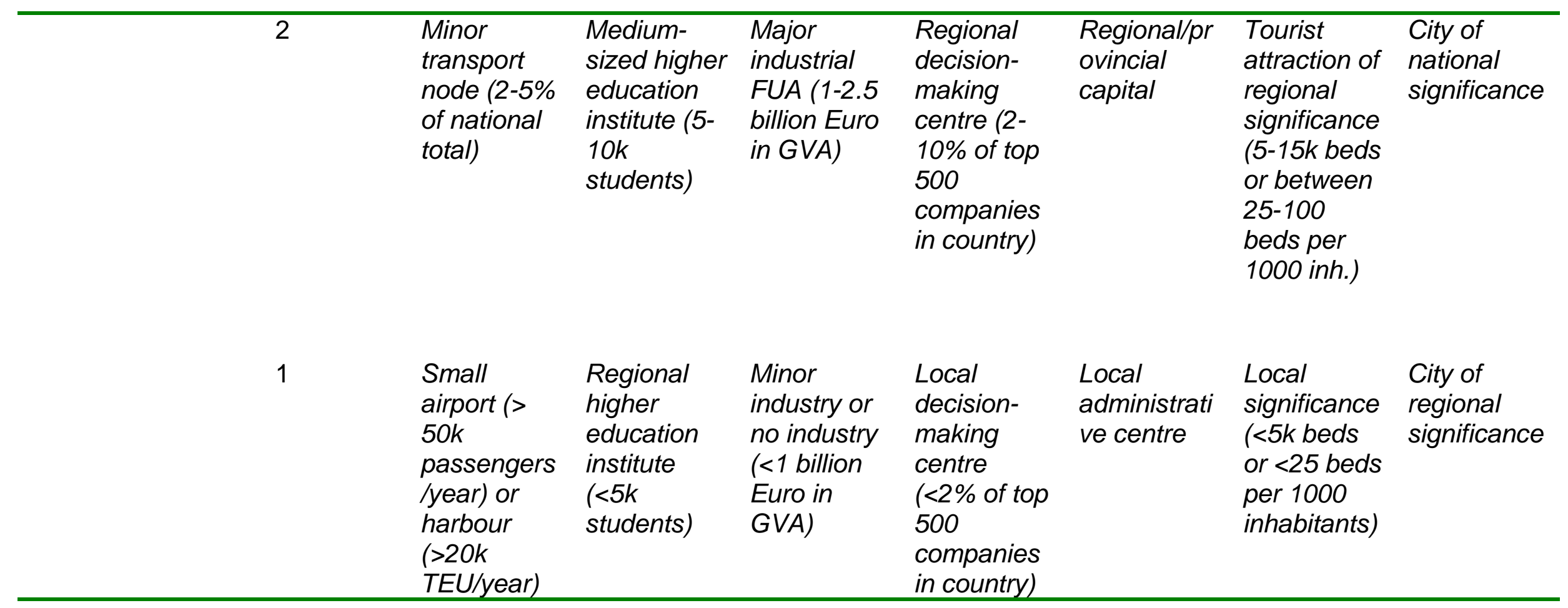


The comparison on Table 2 leads to five important observations regarding critical mass in the Basque autonomous region:

- Taken on their own, the Basque cities only have a minor position in the European urban system;

- Bilbao is the Basque's country major trump in national and international competition;

- The Basque cities do not exploit their critical mass as well as other comparably-sized city-regions;

- In case the Basque urban system truly functions as an urban network, it would be a city-region of European significance (ranking similar to cities such as Sevilla, Porto, Marseille, Turin);

- Further development of a networked Basque urban system is rewarding: it makes the difference between competing as a city region of European importance, or as smaller city regions only of national importance. The potential gain in critical mass can be roughly calculated as being as $22 \%$.

\subsection{Complementarities}

Complementarity means that different cities fulfil different and mutually beneficial roles (Hague and Kirk, 2003). Hence, the challenge is to map the differences between the cities and to see whether these differences between the cities also lead to increased interaction, which can be used as a proxy for being mutually beneficial. In the next subsection, we provide some insight in the spatial interactions between the cities, while in this section the emphasis is on analyzing the differences between the cities. Here, we analyse (potential) complementarities in terms of specialized business services and consumer services of which it is known that they potentially have supralocal significance.

However, before looking at these service sector activities in more detail, we will provide a first and perhaps relatively rough analysis of differences in economic structure of the major Basque cities (comarcas). Given the limited space in this paper, we focus only on complementarities in terms of different economic profiles of the city-regions, however, acknowledging that complementarity can refer to a much broader set of issues in which cities may differ. 
The method used to analyse complementarities in terms of economic activities that is employed here is correspondence analysis. It has been successfully used previously for this purpose, see Meijers (2005; 2007b), and the reader is also referred to Greenacre (1993) for a more detailed account on methodological and statistical aspects of this type of analysis. Correspondence analysis allows us to explore relative differences in economic profile of the three cities and to visualise these. On the bais of this method, a 'complementarity ratio' can be defined with values between 0 (maximum duplication: each city-region as the same economic profile) and 1 (maximum complementarity: each economic activity is uniquely located in just one of the three Basque cities). In Table 4, we present the scores on the complementarity ratio over the 1995-2000-2006 period for differences in the main economic structure between the comarcas in which the major Basque cities are located. Data on the number of employed persons per main class of economic activity (13 in total) was provided by EUSTAT for the three comarcas (Greater Bilbao, San Sebastian and Llanada Alaves) and for the years 1995, 2000 and 2006. The 13 economic sectors are given a weighting on the basis of the number of people employed in each sector. $^{1}$

Table 3 Development complementarity ratio in economic profile of Basque capital cities

\begin{tabular}{llrrrr}
\hline & & 1995 & 2000 & 2006 & $\begin{array}{r}\text { Trend 1995- } \\
\text { 2006 }\end{array}$ \\
\hline $\begin{array}{l}\text { Gran Bilbao-Llanada } \\
\text { Donostialidea }\end{array}$ & Alavesa- & 0,00468 & 0,00416 & 0,00423 & $-9 \%$ \\
\hline
\end{tabular}

Table 3 shows that there are hardly any differences in the economic profiles of the Basque cities. After all, the complementarity ratio varies between 0 (maximum duplication) and 1 (maximum complementarity), and it amounts to just 0,004 for the Basque country. This is extremely low ${ }^{2}$, and means that the Basque capital cities do not, or hardly, complement one another. They all have a very similar economic structure, and this has not changed over the 1995-2006 period.

\footnotetext{
${ }^{1}$ As only employment stratums are known, we calculated the expected number of persons employed in each class of activity ourselves. To do so, we used average values for each size class, for instance 7 for the size class 5-9 employees. For the final class (>50 employees), we used 100 employees as a proxy for the average size of firms in this class.

${ }^{2}$ For instance, in the Dutch Randstad, complemenarities are more than four times as high.
} 
We will now explore the division of labour between the Basque cities in terms of specialised service sector activities. More than with other types of economic activity (e.g. agriculture, manufacturing) it can be assumed that specializations in service sector activities of one place may benefit firms and households in the other places. So, it seems right to assume that the differences found are complementarities indeed. Compared to the previous analysis with the rather rough classification of economic activities in just 13 classes, it is to be expected that this analysis employing a much more detailed classification normally should lead to higher complementarity ratios.

For 69 classes of economic activity, at the 3-digit level of detail of the CNAE-93 classification, data was provided by Orkestra, the Basque Institute of Competitiveness, on the number of people that approximately worked in these 69 classes in 2005 in each of the comarcas ${ }^{3}$ in which the three Basque capital cities are located. While such data was not available for other years, it is not possible to present more information on trends. However, as we saw in the previous analysis, trends appear to show a very stable, robust pattern. Nevertheless, this data allows us to draw a detailed picture of the economic specializations of the Basque cities vis-àvis each other.

Using this more detailed data set on service sector activities (broadly defined) at the 3-digit level of detail provides a remarkable view on the extent to which the different cities are specialized in service sector activities vis-à-vis each other: the complementarity ratio, which varies between 0 (maximum duplication) and 1 (maximum complementarity) amounts to just 0,015. Again, this should be considered extremely low, also compared to polycentric urban regions as the Dutch Randstad $(0,065)$ or the German RheinRuhr $(0,051)$. The service sector activities in the cityregions of Bilbao, Vitoria and San Sebastian duplicate rather than complement each other.

Figure 1 presents the more detailed analysis. This figure should be read as follows. In Figure 1, two axes together indicate the origin $(0,0)$, which resembles the average profile of the four cities. The further a city is away from the origin, the more it contributes to the extent of complementarity. If two cities lie close together, then their economic profiles are more or less similar. The same condition applies to the

\footnotetext{
${ }^{3}$ One exception was made. As the airport of San Sebastian is located in a different Comarca (Bajo Bidasoa), the number of employed people in code 621 'Scheduled air transport', was included in the comarca Donostialdea
} 
economic activities. Economic activities lying close together are more or less similarly distributed between the cities. The distance between cities and economic activities is more complicated, since these are not defined as chi-square distances. All cities influence the location of an economic activity, and conversely, all economic activities contribute to the location of a city. In general, cities and activities will be close to each other when the observed value for this pair of points in the table is larger than expected, and the distance will be large when the observed value is less than the expected value. Figure 1 presents the current division of labour between the cities (as far as there is one). However, for reasons of clarity, out of the 69 economic service activities included in the analysis, only those activities contributing at least $2 \%$ to the complementarity ratio are depicted (each class of economic activity adds to the total inertia indicator, which is then translated into the complementarity ratio). Service activities that do not meet this threshold value are either insignificant in terms of the number of jobs, or because the distribution of jobs in this activity over the three cities is similar to the distribution of all jobs over these cities (for instance, this is the case with class 553 - restaurants and bars). In the latter case, the expected number of jobs in the three cities is more or less equal to the observed number. There are 15 classes of economic activities that meet our threshold of $2 \%$. Together they account for $61 \%$ of the complementarity ratio. However, even within this group there are huge variations in the contribution to the complementarity. The legend of Figure 1 also presents the proportion of the complementarity ratio that is explained by each of the 15 activities. So, the most distinct specialization is 'social work activities' (code 853). 
Figure 1 Most important relative specializations of Basque capital cities, 2005

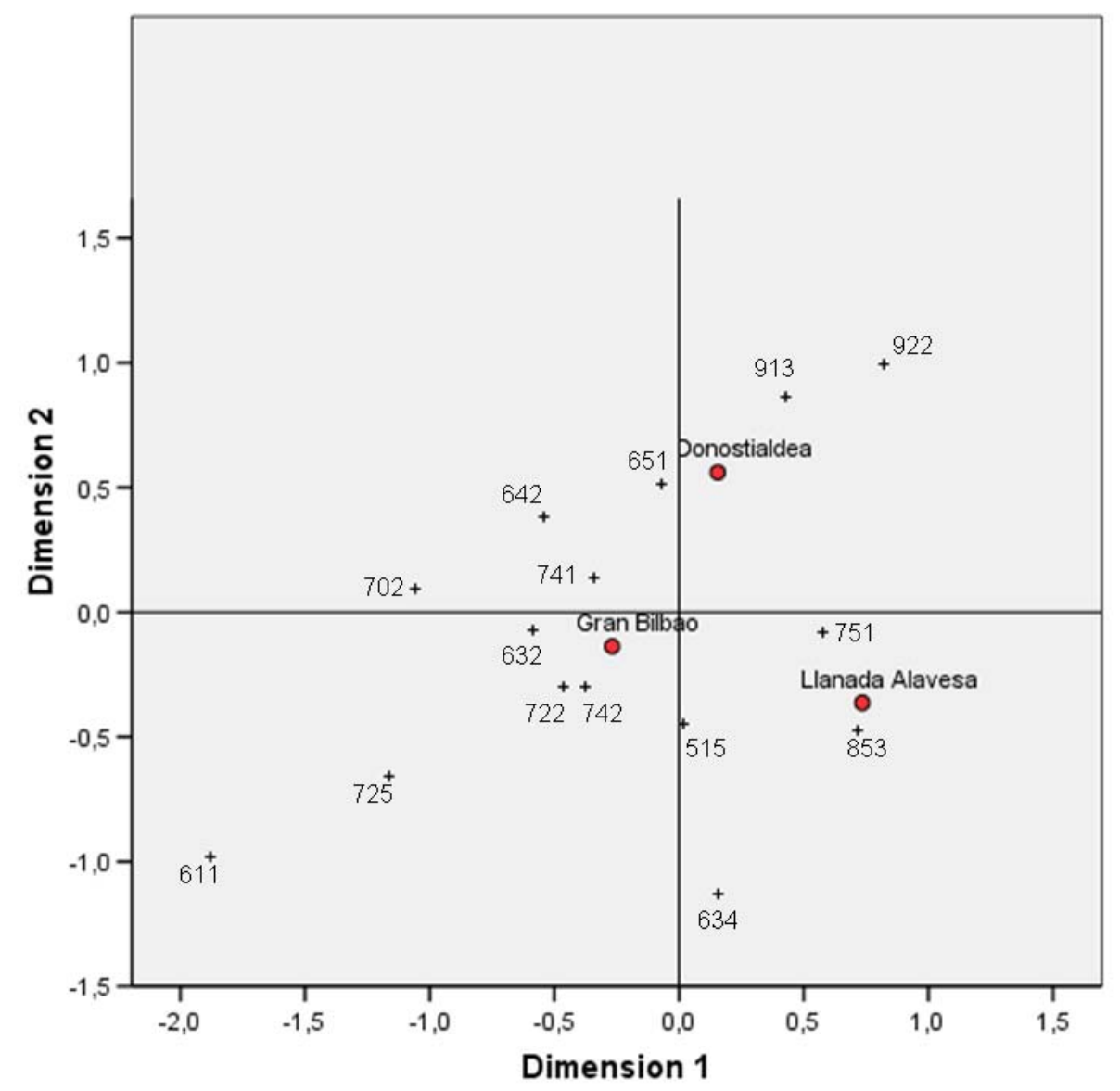

\begin{tabular}{|c|c|c|c|c|c|}
\hline 515 & $\begin{array}{l}\text { Wholesale of non- } \\
\text { agricultural intermediate } \\
\text { products, waste and scrap }\end{array}$ & $\begin{array}{l}2.4 \\
\%\end{array}$ & 725 & $\begin{array}{l}\text { Maintenance and repair of } \\
\text { office, accounting and } \\
\text { computing machinery }\end{array}$ & $2.1 \%$ \\
\hline 611 & $\begin{array}{l}\text { Sea and coastal water } \\
\text { transport }\end{array}$ & $\begin{array}{l}2.5 \\
\%\end{array}$ & 741 & $\begin{array}{l}\text { Legal, accounting, book- } \\
\text { keeping and auditing } \\
\text { activities; tax consultancy; } \\
\text { market research and } \\
\text { public opinion polling; } \\
\text { business and } \\
\text { management consultancy; } \\
\text { holdings }\end{array}$ & $2.9 \%$ \\
\hline 632 & $\begin{array}{l}\text { Other supporting transport } \\
\text { activities }\end{array}$ & $\begin{array}{l}2.1 \\
\%\end{array}$ & 742 & $\begin{array}{lr}\text { Architectural } & \text { and } \\
\text { engineering activities and } \\
\text { related } \\
\text { consultancy }\end{array}$ & $4.2 \%$ \\
\hline
\end{tabular}




\begin{tabular}{|c|c|c|c|c|c|}
\hline 634 & $\begin{array}{l}\text { Activities of other transport } \\
\text { agencies }\end{array}$ & $\begin{array}{l}5.5 \\
\%\end{array}$ & 751 & $\begin{array}{l}\text { Administration of the State } \\
\text { and the economic and } \\
\text { social policy of the } \\
\text { community }\end{array}$ & $9.3 \%$ \\
\hline 642 & Telecommunications & $\begin{array}{l}2.1 \\
\%\end{array}$ & 853 & Social work activities & $12.9 \%$ \\
\hline 651 & Monetary intermediation & $\begin{array}{l}2.5 \\
\%\end{array}$ & 913 & $\begin{array}{l}\text { Activities of other } \\
\text { membership organizations }\end{array}$ & $4.1 \%$ \\
\hline 702 & Letting of own property & $\begin{array}{l}2.4 \\
\%\end{array}$ & 922 & $\begin{array}{l}\text { Radio and television } \\
\text { activities }\end{array}$ & $2.8 \%$ \\
\hline 722 & $\begin{array}{l}\text { Software consultancy and } \\
\text { supply }\end{array}$ & $\begin{array}{l}3.5 \\
\%\end{array}$ & & & \\
\hline
\end{tabular}

From Figure 1 follows that specializations that predominantly locate in Greater Bilbao include transport services (sea and coastal transport; supporting transport activities), ICT-related firms (software consultancy and supply; maintenance and repair of office, accounting and computing machinery), consultancy (legal, accounting, book-keeping and auditing activities, tax consultancy, market research and public opinion polling, business and management consultancy, holdings; architectural and engineering activities and related technical consultancy) and the letting of property. Bilbao shares a specialization with San Sebastian in telecommunications. San Sebastian is relatively specialized in monetary intermediation, activities of membership organizations and radio and television activities. Vitoria is distinct from the other cities by its specialization in social work activities and administration. Vitoria shares a specialization in wholesale activities (of non-agricultural intermediate products, waste and scrap) and activities of transport agencies with Bilbao.

Finally, the further a city is away from the origin in Figure 1, which represents the average profile of the three Basque cities together, the more the city contributes to the total inertia value, and hence, the complementarity ratio. As can be seen in the figure, Vitoria adds most to the complementarity ratio (46\%), followed by San Sebastian (31\%) and finally Bilbao (23\%). However, given the mass of Greater Bilbao, Bilbao also determines most this average profile of the three cities.

\subsection{Interactions}

If the Basque region is functioning as an integrated polycentric urban network indeed, we would expect to find that interaction between the three main Basque cities is relatively high. Strong interactions between cities in polycentric urban regions are an 
indication of complementarity and functional integration. In this section we analyze the flows of people between Bilbao, Vitoria and San Sebastian.

Our analysis is based on a large mobility survey that was carried out by the Basque government: Estudio de la Movilidad de la Comunidad Autónoma Vasca 2007 (Gobierno Vasco, 2007). This study provides insight in the mobility behaviour of the population of Basque country and some neighbouring areas. It is based on a telephonic survey (2006-2007) as well as on questionnaires issued on some strategic points on the Basque infrastructure network (see Gobierno Vasco, 2007 for more detail). The most used unit of analysis in the study is the Comarca as defined by EUstat. This makes it possible to analyze the interaction patterns between the urban regions (comarcas) of Vitoria, Bilbao and San Sebastian.

The Basque mobility study identifies the origin and the destination of each trip. It does not give information on the place of residence of the person who is moving. Consequently, the study can only be used to measure the intensity of the relationships between the three Basque cities. The exact nature of the commuter streams cannot be discerned. As this study does not include all trips, but just trips of over 5 minutes time duration, it follows that figures are biased in the sense that many short-distance trips within cities are ignored.

Table 4 gives insight in the interactions between the urban areas of Bilbao, Vitoria and San Sebastian. The table should be read as follows: of all the trips originating in the comarca of Vitoria $92,1 \%$ has a destination within this comarca, 1,7\% has a destination in the comarca of Bilbao, $0,5 \%$ has a destination in the comarca of San Sebastian and 5,7\% has a destination in some other comarca. The table clearly shows that most trips take place within each of the urban areas. The interactions between the three urban areas have a rather limited share. More than $99 \%$ of all displacements take place within the Basque autonomous region.

Table 4 Interactions within and between the three urban areas (origin of trip in row, destination of trip in column), row percentages

\begin{tabular}{llllll}
\hline & Vitoria & Bilbao & $\begin{array}{l}\text { San } \\
\text { Sebastian }\end{array}$ & Other & Total \\
\hline Vitoria & 92,1 & 1,7 & 0,5 & 5,7 & 100 \\
Bilbao & 0,5 & 92,2 & 0,3 & 7,0 & 100 \\
San & 0,6 & 0,5 & 89,2 & 9,7 & 100 \\
Sebastian & & & & & \\
\hline
\end{tabular}

Source: Gobierno Vasco, 2007 
Some other conclusions that can be drawn on the Basque mobility study in 2007 are:

- There are more movements between Bilbao-Vitoria v.v (25k daily) than between Bilbao-San Sebastian v.v. (10k daily) and San-Sebastian-Vitoria v.v. (9k daily) (see Table 6). In part this is explained by the fact that more people live in Greater Bilbao and that Vitoria and Bilbao are located closer to each other than the other combinations of cities.

- The main travel motive for trips between Bilbao and Vitoria is 'study'. Commuting accounts for the largest share of trips between San Sebastian and Vitoria v.v. 'Work' and 'Personal life' are the most important motives for movements between Bilbao and San Sebastian v.v. (see Table 6).

- Almost half of the movements between Vitoria and Bilbao v.v. take place by public transport. A possible explanation is the fact that many of the people moving do so for study reasons. Public transport serves about one third of the people moving between Bilbao and San Sebastian v.v. Contrarily, the vast majority of movements between Vitoria and San Sebastian v.v. are done by car.

Table 5

Trips between the three Basque urban areas according to motive

\begin{tabular}{|c|c|c|c|}
\hline Work & Study & $\begin{array}{l}\text { Leisure } \\
\text { / } \\
\text { Shoppi }\end{array}$ & $\begin{array}{l}\text { Personal } \\
\text { life }\end{array}$ \\
\hline
\end{tabular}

ng

\begin{tabular}{lllllr}
\hline Vitoria -Bilbao v.v. & 6981 & 13855 & 131 & 4258 & 25225 \\
& $(28 \%)$ & $(55 \%)$ & $(1 \%)$ & $(17 \%)$ & $(100 \%)$ \\
Bilbao - San & 3612 & 2425 & 960 & 3322 & 10319 \\
Sebastian v.v. & $(35 \%)$ & $(24 \%)$ & $(9 \%)$ & $(32 \%)$ & $(100 \%)$ \\
San Sebastian & -5179 & 1650 & 1524 & $568(6 \%)$ & $8921(100 \%)$ \\
Vitoria v.v. & $(58 \%)$ & $(18 \%)$ & $(17 \%)$ & & \\
\hline
\end{tabular}

Source: Gobierno Vasco, 2007

\section{No Basque urban network}

The analysis of critical mass has shown the potential gains for the Basque urban system if it was able to exploit its potential to the full extent. However, our findings strongly suggest that the Basque polycentric urban system has not yet developed 
into a Basque urban network. The three capital cities function as self-standing cityregions, and, taken together, are only a loosely connected city system. This implies that the critical mass, as becomes evident in the extent to which urban functions are specialised, is hardly exploited. Also, the cities hardly complement each other, neither in terms of general economic profile nor in specialised service sector activities.

Being the largest city, it is the strength of Bilbao that largely determines the region's international competitiveness and visibility. Given the very limited extent to which San Sebastian and Vitoria are complementary to Bilbao, it follows that the synergies between the three cities remain limited.

Even though movements between the cities are slightly increasing over the past years, there is no strong evidence that synergies between the cities are about to increase.

\section{THE LEVERAGE OF THE BASQUE TERRITORIAL DEVELOPMENT STRATEGY}

Given our conclusion so-far that the Basque polycentric urban system has progressed not, or only slightly into an urban network in the true sense of the word, and, that as a consequence, synergies between the three cities remain very limited, it seems right to state that the effectiveness of the development strategy for the Basque autonomous region aimed at developing this urban network is very poor.

On the basis of a synthesis of recent European experiences in strategic planning for city-regions, Albrechts et al. (2003) draw several important lessons about the ways in which spatial development strategies can have effective, robust and long-lasting effects. First of all, Albrechts et al. found that strategies that are embedded in local perceptions of challenges and opportunities are more likely to have lasting effects. The second one relates to the acceptance of the spatial strategy, and in particular the spatial concepts it contains, among stakeholders. What is needed are 'strong spatial organising concepts and persuasive institutional alliances to carry a strategy across a diffused power context and through time. A critical task is the formation of policy agendas integrated around some central framing concepts, which can then be translated spatially, so that many parties can grasp the concrete difference it will make to use them.' (p.127). The authors stress the importance of spatial logic and 
metaphors in this process (see also Hajer and Zonneveld, 2000). Also the maps and other cartographic visualisations in the strategy can be very powerful in communicating its key messages (Faludi, 1996; Dühr, 2003). Another lesson relates to the 'ownership' of the strategy and the institutional structure: 'efforts to articulate strategies and practices need to be connected to accountable political levels of government and to formal, legal requirements that affect both regulatory and investment practices' (p.128). A final general lesson they draw about European strategic planning strategies is the acceptance of a strong role for the state and a strong consciousness of place identity.

Some of the factors mentioned by Albrechts et al. (2003) deserve closer attention as they appear to have been the most serious inhibitors of the development of the Basque urban network in the past decade: territorial identity and regional organizing capacity. What is labeled here as 'territorial identities' relates to the local embeddedness and place identity. What we label 'regional organising capacity' addresses the acceptance of stakeholders, political leadership and the role of the state (or, perhaps better in this autonomous region: the role of the central Basque government). We added a third factor, 'infrastructure and distances' which, however, despite being a theme in the strategy, is somewhat less directly connected to the leverage of spatial strategies.

\section{Territorial identities}

Problematic for the development of an urban network is that it requires not only the co-operation of public actors to become a reality, but depends as well on the spatial behaviour of people and firms. More precisely, these actors need to develop a broader regional 'scope'. In the urban sociology and cultural geography literature, it is often emphasized that cultural factors such as territorial identities and attitudes have a strong impact on the way people mentally structure their environment (mental maps) and also make use of territories. For instance, Reicher and Hopkins (2001) state that the ability to get people to imagine themselves as forming a given community and envisage specific forms of social relations as proper and possible is essential in getting them to initiate actions that are aimed at realizing this reality'.

The Basque Country has a strong territorial identity: many Basque people feel strongly connected to the Basque Country. Because of this strong feeling of 
belonging together, we would generally expect to find strong functional relationships in the Basque Country. However, it appeared that local identities, linked to Bilbao, San Sebastian and Vitoria, are even stronger. It seems that inhabitants of these cities are very strongly socially rooted in their own local communities. For Basque people it is very important to live, and to a lesser extent work, in the vicinity of family and friends. This is related to the characteristics of the Southern European welfare states, in which a relatively large part of the welfare tasks (for example child care, care for the elderly) is carried out by the family instead of by the state or the market. The intensive intra-family relations in which this results require residential propinquity (see Hoekstra, 2005). Therefore, chances are high that someone who lives in San Sebastian for instance, is also born there. There appears to be a strong resistance to move between places, especially over a larger distance. The strong place attachment also implies that people, and perhaps also firms, are very much oriented locally when looking for activities (jobs, shopping, cultural amenities) to fulfil their needs. Compared to other countries, Basque people tend to live rather close to their working location. The schedule of working hours also plays a role here. Many Basques still work in morning and afternoon shifts with a large lunch break in between. With such a work schedule, commuting over larger distances is not very attractive because it means one cannot have lunch at home and is away from the early morning till the late afternoon (typically more than twelve hours).

The strong local attachment is also fostered by several policies and regulations in place. In particular the Basque housing market and housing policies have some structural characteristics that hamper mobility. First of all, there is a limited supply of rental dwellings. This makes it difficult for young people with a low income to leave their parental house and start to live on their own (for example to start a 'new' life in another city). Consequently, many young people keep on living in their parental house until they have saved enough money to buy a house (often with financial aid from the family: house prices in the three main Basque cities are comparable to those of metropolises as Madrid en Barcelona, while wages are generally lower). Often, they only reach this point when they already have a steady job and relationship and are over 30 years old. At that point, the chances of moving to another city are already rather low. In an attempt to solve the housing problems for young households, the different levels of government (regional government, 
municipalities) provide subsidized owner-occupancy housing (Vivienda de Protection Official) for lower and middle income groups. However, some of these subsidized dwellings are only accessible for people that are already living in the area in which the dwellings are built (see Haffner and Hoekstra, 2006). It goes without saying that this restriction hampers intermunicipal mobility.

As a result of the strong local orientation in Basque country, the autonomous region merely consists of a set of different local housing, labour and consumer good markets. The interactions between the different areas in the region are still too limited to speak of one integrated regional market.

\section{Regional organising capacities}

Public administration tends to be organised in a territorial hierarchy. However, cooperation in polycentric urban regions involves multiple scales and cuts across several administrative tiers. Additionally, multi-level governance requires the involvement of multiple public, private and organised interest groups, thereby taking into account that different issues call for different alliances with different spatial competencies and life spans. Therefore, the exploitation of the theoretical potential of the polycentric Basque urban system not only concerns co-operation between cities, but rather, the development of what can be coined as 'regional organising capacity'. The concept of regional organising capacity (Meijers and Romein, 2003) refers to the ability to regionally co-ordinate developments through a more or less institutionalised framework of co-operation, debate, negotiation and decision-making in pursuit of regional interests in which a multitude of public and private stakeholders participate. To what extent positive externalities arise from co-operation obviously depends on the utilisation and functioning of such frameworks (see Capello, 2000), for instance with respect to the level of interaction, the willingness and ability of participating actors to set aside local interests for the greater regional good and the avoidance of free-rider behaviour.

A typical problem in polycentric urban regions is the lack of 'political ownership' of issues that require to be addressed at the regional scale rather than the local. However, at first sight, the Basque political-institutional system seems to be quite well equipped to address regional issues: the Basque autonomous region is positioned at the right spatial scale to deal with the coherent development of the Basque urban system, ruling over all its cities. Moreover, it has formal competencies 
in spatial planning and territorial development. However, the historically rooted strong autonomy of the three provinces and their large financial power as a result of their responsibility for tax collection makes the addressing of cooperation issues and regional coordination of spatial development more complicated. In particular strategic regional projects that may harm the tax base of one province in favour of another province seem not easy to accomplish. It appears that proper instruments that allow for a trade-off of costs and benefits, which occur at different points in time and often do not accrue to the same actors, are lacking. More generally, it appears that provinces are not very convinced of the need to set aside their interests for the pursuit of the greater 'regional good'. This also implies that the potential gains of such a more 'regional focus' have not been demonstrated and communicated sufficiently.

\section{Infrastructure and distances}

Huge investments in the past decade have significantly improved the road infrastructure between the cities. Also, congestion remains largely limited to the entrance of cities from the motorways, rather than on the motorways themselves. Nevertheless, there are still some hampering factors. For example, the highway between San Sebastian and Bilbao is rather narrow which means that accidents quickly lead to a complete closure of the road and serious traffic jams. Furthermore, the highways between San Sebastian and Bilbao and Bilbao and Vitoria are toll roads. This significantly adds to the travel costs and probably has a negative influence on people's willingness to travel by car between the mentioned cities.

As far as public transport is concerned, the bus is more important than the train. There are frequent buses between the three cities and the prices of bus travel are low compared to travel by car. The train is less important, due to the long travel time (especially for the connection between San Sebastian and Bilbao) and the limited frequency (all intercity connections).

In our opinion, the current travel distances between the cities (expressed in travel time and costs) remain just beyond the limits that many Basque people are willing to travel, certainly for trips made on a daily basis. This holds comparatively more for the trips between Vitoria and San Sebastian v.v. and San Sebastian and Bilbao v.v., as the Vitoria-Bilbao trip requires less time and money. 
Obviously, the improvement of infrastructure connecting the cities is the most straightforward means of knitting the three cities more together. In particular the improvement of the train connections between the three cities is of importance. As far as this is concerned, the Y-vasca, a high speed train line, which will link Bilbao and San Sebastian with Vitoria and onwards to Madrid and across the French border, is a key project. A better and faster train connection between the three main Basque urban areas could possibly make the difference between the Basque urban system being a loosely connected urban system or a fully integrated urban network. Moreover, it also allows for a better integration of Basque country with other important European areas. In addition, the apparent reluctance of Basque people to move house between the three cities is another argument that makes this infrastructure development desirable. The high speed train will allow people to continue living in the place in which they are socially rooted, while it opens up opportunities for work and study in the other cities. However, in the Basque autonomous region, the development of this high-speed line is a controversial issue. Opponents have environmental concerns and stress the need to give priority to train connections at the city-regional level. At the background geopolitical and ideological considerations probably also play a role.

\section{CONCLUSION: PLANNING FOR URBAN NETWORKS}

According to Healey (2006: 527) 'strategic spatial planning endeavours are themselves complex governance processes, through which concepts of spatial organization are mobilized with the ambition of accumulating sufficient allocative, authoritative and imaginative force to shape both the materialities and identities of particular places.' This force needs to be strong in a polycentric urban region, as such a region can be characterised as a 'socio-spatial conflict zone for articulation of multiple interests, identities and cultural differences' (Albrechts, 2001: 734). Key elements of a planning approach in polycentric urban regions are selectivity, dialogue, diversity, networking, contextuality, the creation of vision and frameworks, mobilising, institution-building and action-orientation (Albrechts, 2001). A careful selection of key strategic projects where obvious synergies can be maintained is another. 
Given our finding that in the Basque autonomous region only some initial steps towards the formation of a true urban network between Bilbao, San Sebastian and Vitoria have been taken, it appears that the process of strategic planning has not been finished properly. It seems to have ended with a document representing a shared collective vision for the future development, but afterwards, this vision has not been carried further. In that sense, the allocative, authoritative and imaginative power of the Euskal Hiria strategy was too limited.

If the polycentric urban system of the Basque Country is to really develop into an urban network allowing for synergies between the cities, then a renewed, shared and stronger effort needs to be made by all regional stakeholders.

\section{REFERENCES}

Albrechts, L. (2001) How to Proceed from Image and Discourse to Action: As Applied to the Flemish Diamond, Urban Studies, 38, pp. 733-745.

Albrechts, L., Healey, P. and K.R. Kunzmann (2003) Strategic Spatial Planning and Regional Governance in Europe, Journal of the American Planning Association, 69, pp. 113-129.

Batten, D.F. (1995) Network Cities: Creative Urban Agglomerations for the 21st Century, Urban Studies, 32, pp. 313-327.

Camagni, R. and C. Salone (1993) Network Urban Structures in Northern Italy: Elements for a Theoretical Framework, Urban Studies, 30, pp. 1053-1064.

Capello, R. (2000) The City Network Paradigm: Measuring Urban Network Externalities, Urban Studies, 37, pp. 1925-1945.

CEC, Commission of the European Communities (1999) European Spatial Development Perspective: Towards Balanced and Sustainable Development of the Territory of the EU. Luxembourg: Office for Official Publications of the European Communities.

CEMAT, European Conference of Ministers responsible for Spatial/Regional Planning of the Member States of the Council of Europe (2006) Resolution $N^{\circ} 1$ on Polycentric development: promoting competitiveness, enhancing cohesion, 
adopted at the 14th CEMAT Session in Lisbon on 27 October 2006 (http://www.coe.int/t/dg4/cultureheritage/Source/Policies/CEMAT/14CEMAT Re solution1 en.pdf), last accessed 21 May 2008)

Council of the European Union (2006) Community Strategic Guidelines on Cohesion, (2006/702/EC), Council Decision of 6 October 2006, Official Journal of the European Union, 21-10-2006, L291: 11-32.

Davoudi, S. (2003) Polycentricity in European Spatial Planning: From an Analytical Tool to a Normative Agenda, European Planning Studies, 11, pp. 979-999.

Dieleman, F.M. and A. Faludi (1998) Randstad, Rhine-Ruhr and Flemish Diamond as one Polynucleated Macro-Region?, Tijdschrift voor Economische en Sociale Geografie, 89, pp. 320-327.

Dühr, S. (2003) Illustrating Spatial Policies in Europe, European Planning Studies, 11, pp. 929-948.

EU Ministers Responsible for Spatial Planning and Development (2007) Territorial Agenda of the European Union - Towards a More Competitive and Sustainable Europa of Diverse Regions (Final Draft), (http://www.bmvbs.de/Anlage/original_1005295/Territorial-Agenda-of-theEuropean-Union-Agreed-on-25-May-2007-accessible.pdf); last accessed 21 May 2008).

Faludi, A. (1996) Framing with images, Environment and Planning B, 23, pp: 93-108.

Faludi, A. (2005) Territorial Cohesion: An Unidentified Political Objective Introduction to the special issue, Town Planning Review, 76, pp. 1-13.

Faludi, A. (2006) The European Spatial Development Perspective - Shaping the Agenda, European Journal of Spatial Development, Refereed Articles Nov 2006 no 21, http://www.nordregio.se/EJSD/.

Faludi, A. and B. Waterhout (2002) The Making of the European Spatial Development Perspective. No Masterplan! London/New York: Routledge.

Franco, H. and G. Extebarria (2005) La función del sistema de ciudades en el desarollo regional. Potencialidad y limitaciones de la región urbana polinuclear vasca, Ekonomiaz, 58, pp. 232-261. 
Gobierno Vasco (1997) Directrices de Ordenacion Territorial de la Comunidad Autonoma del Pais Vasco (DOT Euskadi). Vitoria-Gasteiz: Eusko Jaurlaritza.

Gobierno Vasco (2002) Euskal Hiria, Proyecto Cities. Vitoria-Gasteiz: Servicio Central de Publicaciones del Gobierno Vasco.

Gobierno Vasco, (2003) Estudio de la Movilidad de la Comunidad Autónoma Vasca 2003. Vitoria-Gasteiz: Gobierno Vasco, Departamento de Transportes y Obras Públicas.

Gobierno Vasco (2007) Estudio de la Movilidad de la Comunidad Autónoma Vasca 2007. Vitoria-Gasteiz: Gobierno Vasco, Departamento de Transportes y Obras Públicas.

Greenacre, M.J. (1993) Correspondence analysis in practice. London: Academic Press Limited.

Haffner, M.E.A and J.S.C.M. Hoekstra (2006) Housing allocation and freedom of movement. A European comparison, Tijdschrift voor Economische en Sociale Geografie, 97, pp. 443-451.

Hague, C. and K. Kirk (2003) Polycentricity scoping study. London: Office of the Deputy Prime Minister.

Hajer, M.A. and W. Zonneveld (2000) Spatial Planning in the Network Society Rethinking the principles of planning in the Netherlands, European Planning Studies, Vol. 8, pp. 337-355.

Hall, P. and K. Pain (Eds) (2006) The Polycentric Metropolis: Learning from megacity regions in Europe. London: Earthscan.

Healey, P. (2006) Relational complexity and the imaginative power of strategic spatial planning, European Planning Studies, 14, pp. 525-546.

Hoekstra, J. (2005) Is there a relationship between welfare state regime and dwelling type? An exploratory statistical analysis, Housing Studies, 20, pp. 475-495

Houtum, H. van and A. Lagendijk (2001) Contextualising Regional Identity and Imagination in the Construction of Polycentric Urban Regions: The cases of the Ruhr Area and the Basque Country, Urban Studies, 38, pp. 747-767. 
Instituto Vasco de Competividad (eds. Navarro Arancegui, M., Larrea Atanguren, and M.J. Aranguren Querejeta) (2007) Indicadores y análisis de competitividad local en el País Vasco, Ekonomiaz 1, Vitoria-Gasteiz: Servicio Central de Publicaciones del Gobierno Vasco.

Kloosterman, R.C. and B. Lambregts (2001) Clustering of Economic Activities in Polycentric Urban Regions: The Case of the Randstad, Urban Studies, 38, pp. 717-732.

Kloosterman, R.C. and S. Musterd (2001) The Polycentric Urban Region: Towards a Research Agenda, Urban Studies, 38, pp. 623-633.

Knaap., G.A. van der (2002) Stedelijke bewegingsruimte, over veranderingen in stad en land. The Hague: Sdu Uitgevers.

Lambregts, B. (2000) Background study and theoretical framework for the Eurbanet project, Eurbanet report to the European Commission, Delft: OTB Research Institute.

Meijers, E. (2005) Polycentric Urban Regions and the Quest for Synergy: Is a Network of Cities More than the Sum of the Parts?, Urban Studies, 42, 765-81.

Meijers, E. (2007a) From Central Place to Network Model: Theory and Evidence of a Paradigm change, Tijdschrift voor Economische en Sociale Geografie, 98, 24559.

Meijers, E. (2007b) Clones or Complements? The division of labour between the main cities of the Randstad, the Flemish Diamond and the RheinRuhr Area, Regional Studies, 41, 889-900.

Meijers, E. and Romein, A. (2003) Realizing potential: Building Regional Organizing Capacity in Polycentric Urban Regions, European Urban and Regional Studies, $10,173-86$.

Meijers, E., Waterhout, B. and W. Zonneveld (2007) Polycentric development policies in European Countries: An introduction, Built Environment, 31, pp. 97-102.

Nordregio et alia (2004) ESPON 1.1.1: Potentials for polycentric development in Europe, Project report. Stockholm/Luxembourg: Nordregio/ESPON Monitoring Committee. 
Parr, J.B. (2004) The Polycentric Urban Region: A Closer Inspection, Regional Studies, 38, pp. 231-240.

Priemus, H. (1994) Planning the Randstad: Between Economic Growth and Sustainability, Urban Studies, 31, pp.509-534.

Priemus, H., Zonneveld, W. and A. Faludi (Eds) (2004) Special Issue: Territorial Governance in Polynuclear Urban Regions in Northwest Europe, European Planning Studies, 12(3).

Reicher, S. and N. Hopkins (2001) Self and Nation. London: Sage.

Salet, W. and A. Faludi (2000) The revival of strategic spatial planning. Amsterdam: Royal Netherlands Academy of Sciences.

Tatzberger, G. (2008) A Global Economic Integration Zone in Central Europe? Vienna-Bratislava-Györ as a Laboratory for EU Territorial Cohesion Policy. PhD Thesis, Delft University of Technology. 


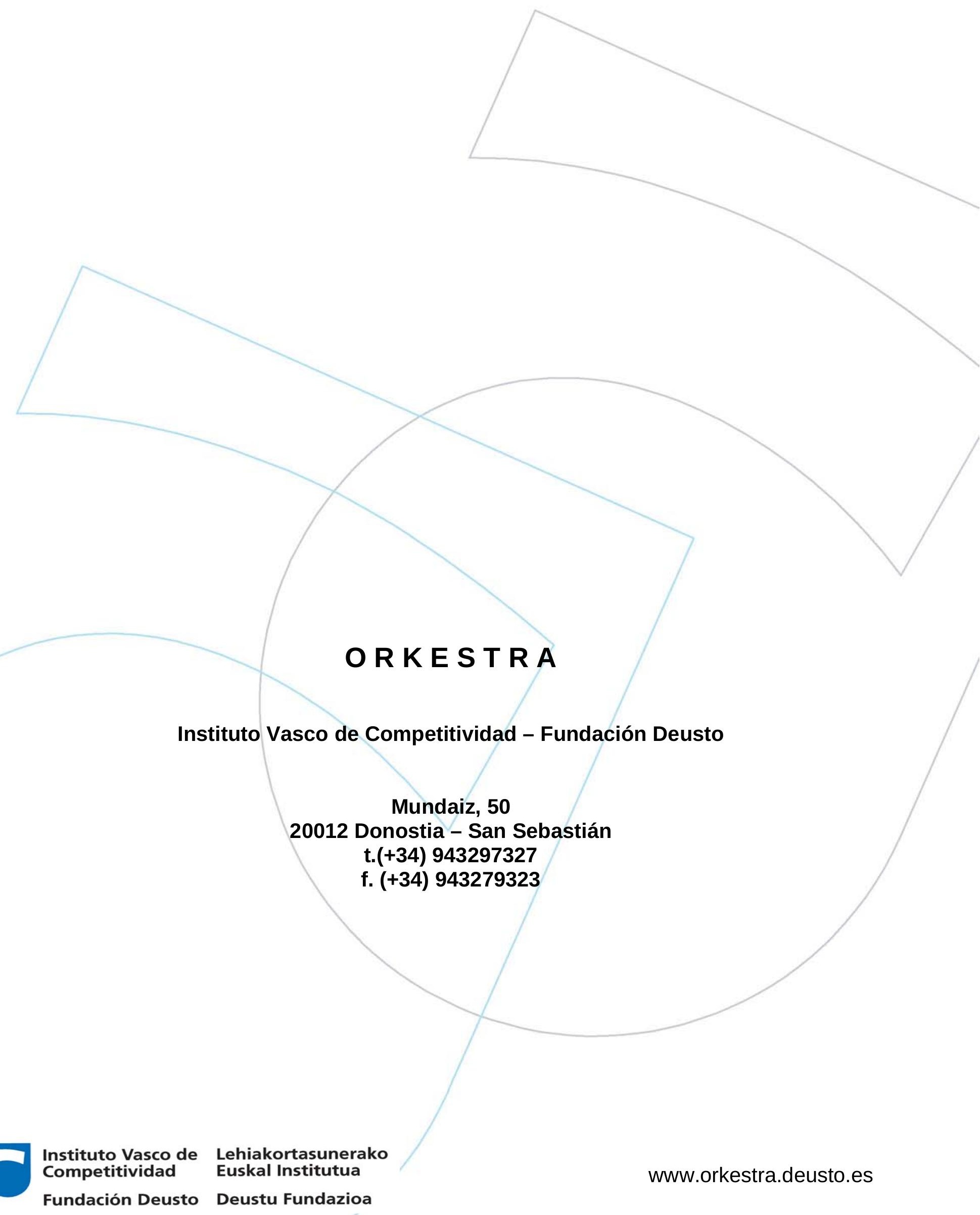

